\title{
Digitalizing Learning Materials on Evaluation im Deutschunterricht Course
}

DOI: https://doi.org/10.47175/rielsj.v2i4.345

\author{
1,2,3 Department of German \\ Language, Universitas Negeri \\ Malang, Malang, Indonesia \\ Primardiana.hermilia.fs@um.ac \\ id
}

| Primardiana H. Wijayati ${ }^{1,{ }^{*}}$ | Silmy M. Mawardah² | Tamara C. Fitrisia ${ }^{3}$ |

\begin{abstract}
The purpose of this research and development was to develop learning materials in the form of digital books based on the Flip PDF Professional application to support the Evaluation Im Deutschunterricht course. This development research used the $4 D$ development model of S. Thiagarajan, Dorothy S. Semmel, and Melvyn I. Semmel, namely (1) Define, (2) Design, (3) Develop, (4) Disseminate. The research subjects were students of the German Language Education study program who took Evaluation Im Deutschunterricht course in 2021. This research used a questionnaire instrument. Descriptive quantitative analysis technique was employed to analyse the questionnaire data from class $C$ students that responses to the digital book and questionnaire data from the validity test of digital book. The content of the book was analysed using Gregory's content validity theory (2016). The validation results from material expert and media expert indicate that the developed digital book is included in the very high content validity category with a result of 0.96 . The results of the implementation to the students indicated that the digital book has an attractive appearance, easy to understand, easy to access, support interaction between lecturers and students, and can improve the learning process. The two results indicated that the digital book for the Evaluation Im Deutschunterricht course is proper to be used on the learning process.

KEYWORDS

digital book; Evaluation Im Deutschunterricht; teaching material; Flip PDF Professional
\end{abstract}

\section{INTRODUCTION}

The education world demands a revolution in learning which was conducted offline, today more learning activities are conducted online. Teachers need some creations so that the learning can be accepted by learners. Nowadays, digitalized information is rapidly spread out and requires both lecturers and students to move effectively and efficiently (Purwati \& Nugroho, 2018).

Along with the appearance of the covid-19 pandemic and 4.0 industry revolution, the government of Indonesia facilitates the education discipline by constructing a digital book by the National Education Department of Indonesia (Ghofur \& Kustijono, 2015; Ruddamayanti, 2019). A digital book is a book which is published and can be accessed in digital or electronic form. According to Atmadja et al. (2015) dan Saefullah (2017) the digital book is an innovation in preserving printed books that need extra care.

Herliantari (2020) states that the presence of the digital book is essential today. A digital book can be a solution for the limited printed book. The digital book is published in the form of a soft file. Thus, it is more efficient and less costly in its distribution. The digital book can 
be used as a supplementary source for students to learn independently using technology (Andina, 2011; Endryanti et al., 2020; Sofyan \& Listiawan, 2019).

According to Tarigan \& Tarigan (2009), a book is considered as an interesting book if it is relevant to the curriculum which is used in the learning, if it comprises clear concept, if it can increase the users' motivation and interest to read, if it provides illustration and visual that stimulates the readers, if it uses concise and comprehensible language in the materials. Dewi (2015) claims that an interesting digital book does not only cover texts, but also interactive media that are accessible for readers, while Hwan (2017) and Jeong (2013) in (Indariani, et al., 2019) stated that a digital book needs to be interactive in nature, which includes images, audios, videos, and quizzes by considering balanced colour composition and interesting layout that supports the lecturers and students interaction.

According to Wirasasmita \& Uska (2017), lecturing which applies a digital book enable students to understand the learning materials. This is also in line with the research result by (Aji \& Widjanarko, 2016; Muhammad et al., 2017; Suyasa \& Divayana, 2018) that students' learning outcomes increase. Moreover, the students gave good responses to the digital book because it uses multiply and interesting platforms that motivate them (Marlina, et al., 2021).

Many software or platforms or application that function as a digital book maker, such as 3D PageFlip, Kvisoft Flipbook Maker, Flip PDF Professional and many others. However, FLIP PDF Professional is the easiest platform for a beginner. This is an application to create a digital book which provides page editing feature and interactive buttons for images, personal video, video from youtube, audio, hyperlinks, quiz, and so on (Seruni, et al., 2020). Nurjayadi, et al. (2021) state that a digital book from Flip PDF Professional can be accessed through a personal computer and smartphone. The format of the book can be in the form of HTML, EXE, Zip, Mac App, FBR, Mobile version, and Burn to CD.

The digital book is believed to be helpful for lecturing, especially in Evaluation im Deutschunterricht (German Language Assessment) in German Department of Universitas Negeri Malang. The objective of this course is to enable students to control their learning outcomes, increase their academic knowledge, and increase the quality of learning (Harsalinda \& Wijayati, 2018). The Evaluation Im Deutschunterricht course is a compulsory course which includes basic theories of language evaluation and learning of German (Jurusan Sastra Jerman Universitas Negeri Malang, 2020).

Harsalinda \& Wijayanti (2018) state that the materials in Evaluation Im Deutschunterricht course is opaque and full of theories. This material needs a digital book as a supplementary source. A few digital books for Evaluation Im Deutschunterricht course have been developed, therefore many students feel difficulty in comprehending the materials which are abstract and theoretical in nature.

Considering the above-mentioned problems, the development of a digital book for Evaluation Im Deutschunterricht course is necessary. It aimed at digitalizing the learning materials on Evaluation Im Deutschunterricht course that meet the criteria of a digital book.

\section{RESEARCH METHODS}

This research employed Research and Development (R\&D) design. This research was conducted by implementing the 4-D development model of S.Thiagarajan, Dorothy S.Semmel, dan Melvyn I. Semmel which consists of four phases, namely define, design, develop, disseminate (Thiagarajan et. al., 1974). The four phases are visualized in the following diagram. 


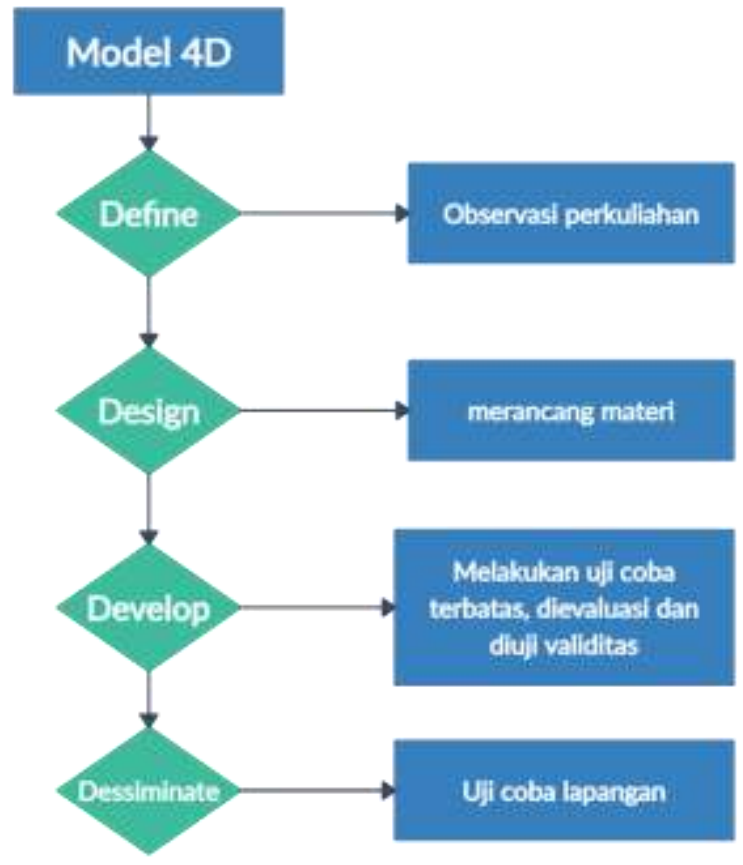

Diagram 1. The visualization of the 4-D Research and Development Model

In the define phase, the researcher observed a classroom lecture of Evaluation Im Deutschunterricht course. Analysis of curriculum, lesson plans, and learning materials used by the lecturer were carried out.

In the next phase, the researcher designed and construct the content and the digital book design which would be developed. In the develop step, the researcher tried out the product of digital book, asked her students to evaluate it, and asked for experts of media and learning materials to validate the product. In the disseminate phase as the last step, the researcher administered wider scope try out. This action was considered to extend the users of the completely developed digital book through SIPEJAR and SPADA UM.

The subject of the narrow scope try out were students who enrolled in Evaluation Im Deutschunterricht course from class A and class B, while the subject of wider scope try out were students from class $\mathrm{C}$ under the equal subject. Two research instruments were applied in the form of an evaluation questionnaire which was committed to be delivered to students and a validity questionnaire for experts of media and learning material. The questionnaires were applied to record the evaluation commotion of the constructed digital book from the perspective of the students. Meanwhile, the validation form was used to measure the content of the digital book so that lacking can be minimized and revised.

The questionnaires consist of the compilation of theories of the definition of digital book by Dewi (2015); Indariani et. al. (2019); Tarigan \& Tarigan (2009). The data were obtained through content validity test which was analyzed using content validity measurement by Gregory (2016). The data which were obtained from the students' responses were analyzed descriptive quantitatively.

\section{RESULTS AND DISCUSSION}

The present research and development was conducted under four phases, namely define, design, develop, and disseminate 


\section{Define}

In this phase, the researcher performed a need analysis of the developed digital book. The result showed that the necessity of a digital book which is in line with the curriculum and syllabus of Evaluation Im Deutschunterricht is quite high. Several selected materials to be included in this book were a) evaluation, measurement, and test; b) test and non-test; c) Übungen dan Aufgaben; d) Fehler dan Fehlerkorrektur; e) Bloom Taxonomy; f) language competence; g) literature competence; h) CEFR and GER; i) item analysis; j) validity; and k) reliability. The blueprint of the book consisted of related works of literature, exercises or assignments, examples, and references to help students to understand the explanation of the presented theories. Each theory involved references to enable the students to find out the primary sources in detail.

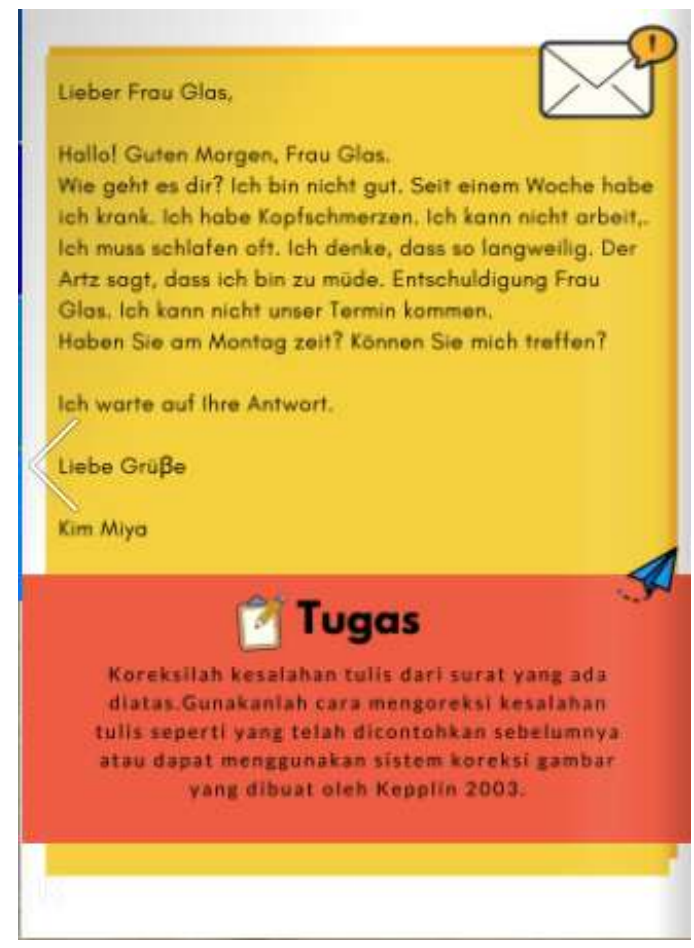

Figure 1. HOTS Based Assignment in The Digital Book

\section{Design}

In design phase, the researcher compiled various materials and wrote the materials in Microsoft Word, arranged the layout of the digital book on Canva, and edited the digital book by adding several interactive multimedia through Flip PDF Professional. This phase was carried out during the administration of the narrow scope try out based on the evaluation result from students and validity from experts. The complete design was done during the wider scope try out after finishing the eleventh materials on Evaluation im Deutschunterricht course.

\section{Develop}

The third phase was develop. In this phase the researcher constructed the digital book which was called prototype 1 . 


\section{Narrow Scope Try Out}

Prototype 1 was tried out to German Education students who took Evaluation Im Deutschunterricht course class A and B. The narrow scope try out was administered eleven times for eleven materials. In this stage, the instrument used was a questionnaire to record the students' responses, suggestions, and criticizes towards the digital book.

Based on the questionnaire, it is proven that the students could hardly access the digital book, especially at the first to seventh materials due to the file capacity and could not be accessed via smartphone. Thus, the researcher revised the digital book so that it is accessible through smartphone at the eighth meeting.

\section{Validity Test}

The validity test of the present digital book was conducted by two experts of learning material and learning media. The content of the digital book was validated using a formula by Gregory (2016) the formula is useful when there are many variables to be measured by a researcher.

The two validators used the identical instrument which consisted of a) interactive multimedia aspect which focused on the multimedia items inside the digital book; b) interesting visual aspect, which included variable items of the vantage point of the digital book; c) materials aspect which consisted of presented materials; d) students-lecturers interaction aspect; and e) learning improvement aspect. The following table shows the blueprint of the validity test questionnaire. The blueprint was constructed based on the theories compilation of the definition of digital book by previous researchers (Dewi, 2015; Indariani et al., 2019; Tarigan \& Tarigan, 2009).

Tabel 1. The Blueprint of Validity Test Instrument

\begin{tabular}{|c|c|c|c|}
\hline No & Variables & Variable Items & $\begin{array}{c}\text { No } \\
\text { Item }\end{array}$ \\
\hline \multirow{6}{*}{1.} & \multirow{6}{*}{$\begin{array}{l}\text { Interactive Multimedia } \\
\text { Aspect }\end{array}$} & a. The relevance of images in the digital book & 1. \\
\hline & & b. The relevance of the audios in the digital book & 2. \\
\hline & & c. The clarity of the audios & 3. \\
\hline & & d. The relevance of the videos in the digital book & 4. \\
\hline & & e. The presentable of the videos & 5. \\
\hline & & f. The appropriateness of feedback for users & 6. \\
\hline \multirow{6}{*}{2.} & \multirow{6}{*}{ Interesting visual Aspect } & a. Interesting design & 7. \\
\hline & & b. Balanced colour & 8. \\
\hline & & c. The coherence of the layout of the digital book & 9. \\
\hline & & d. Balanced texts in the digital book & 10. \\
\hline & & e. Simple but accurate information & 11. \\
\hline & & f. Emphasize on important information & 12. \\
\hline \multirow{5}{*}{3.} & \multirow{5}{*}{ Materials aspect } & a. The suitability of materials and syllabus & 13. \\
\hline & & b. The comprehensiveness of materials & 14. \\
\hline & & $\begin{array}{l}\text { c. The appropriateness of exercises and the } \\
\text { materials }\end{array}$ & 15. \\
\hline & & $\begin{array}{l}\text { d. The exercises/assignment explore the } \\
\text { students' critical thinking. }\end{array}$ & 16. \\
\hline & & $\begin{array}{l}\text { e. The audios help students to understand the } \\
\text { materials }\end{array}$ & 17. \\
\hline
\end{tabular}




\begin{tabular}{|c|c|c|c|}
\hline & & $\begin{array}{l}\text { f. The videos help students to understand the } \\
\text { materials }\end{array}$ & 18. \\
\hline & & g. Clear statements/no ambiguity statements. & 19. \\
\hline & & h. Communicative & 20. \\
\hline \multirow{5}{*}{4.} & \multirow{5}{*}{$\begin{array}{l}\text { Students-Lecturers } \\
\text { Interaction aspect }\end{array}$} & $\begin{array}{l}\text { a. The digital book increases the students } \\
\text { independence }\end{array}$ & 21. \\
\hline & & $\begin{array}{l}\text { b. The lecturers do not need to explain the } \\
\text { material in detail }\end{array}$ & 22. \\
\hline & & $\begin{array}{l}\text { c. The digital book enhances students } \\
\text { autonomous learning }\end{array}$ & 23. \\
\hline & & d. Accessible & 24. \\
\hline & & e. Practicality & 25 . \\
\hline \multirow{2}{*}{5.} & \multirow{2}{*}{$\begin{array}{l}\text { Learning improvement } \\
\text { aspect }\end{array}$} & a. The students are motivated to learn & 26. \\
\hline & & b. Improve the students' comprehension & 27. \\
\hline
\end{tabular}

Meanwhile, the results of the validity test of the digital book on Evaluation Im Deutschunterricht course are presented in the following table 2.

Table 2. Results of the validity test

\begin{tabular}{|c|c|c|c|}
\hline \multicolumn{2}{|c|}{$\begin{array}{l}\text { Experts on learning } \\
\text { materials }\end{array}$} & \multicolumn{2}{|c|}{$\begin{array}{l}\text { Expert on learning } \\
\text { media }\end{array}$} \\
\hline irrelevant & relevant & irrelevant & relevant \\
\hline 22. & $\begin{array}{ll}1,2,3,4, \\
5,6,7,8, \\
9,10,11, \\
12, & 13, \\
14, & 15, \\
16, & 17, \\
18, & 19, \\
20, & 21, \\
23, & 24, \\
25, & 26, \\
27 . & \end{array}$ & - & $\begin{array}{l}1,2,3,4, \\
5,6,7,8, \\
9,10,11, \\
12, \quad 13, \\
14, \quad 15, \\
16, \quad 17, \\
18, \quad 19, \\
20, \quad 21, \\
22, \quad 23, \\
24, \quad 25, \\
26,27 .\end{array}$ \\
\hline
\end{tabular}

In table 2 it is revealed that the expert of learning media suggested that all aspects in the digital book which was developed are relevant. Meanwhile, according to the expert of learning material, there was an irrelevant item from the students-lecturers interaction aspect.

The results of the validity test from both experts were calculated using the content validity formula by Gregory (2016):

\section{Content validity $=\frac{D}{A+B+C+D}$}

Note:

$\mathrm{A}=$ both raters disagree

$\mathrm{B}=$ Rater I agree, rater II disagree

$\mathrm{C}=$ Rater I disagree, rater II agree

$\mathrm{D}=$ both raters agree

The criteria of content validity:

$0,80-1,00 \quad$ : very high 


$$
\begin{array}{ll}
0,60-0,79 & : \text { high } \\
0,40-0,59 & : \text { moderate } \\
0,20-0,39 & : \text { low } \\
0,00-0,19 & : \text { very low }
\end{array}
$$

$$
\begin{aligned}
& \text { content validity }=\frac{26}{0+0+1+26} \\
& \text { Content validity }=0.96
\end{aligned}
$$

The result of the content validity from both validators is 0.96 . based on the result of Gregory (2016) formula above, it is revealed that the validity of the present Flip PDF Professional based digital book on Evaluation Im Deutschunterricht course is very high. It shows that the digital book is appropriate to be used on Evaluation Im Deutschunterricht course.

\section{Disseminate}

In this phase, the product of digital book, which had been tried out and undergone validity test, was disseminated and implemented to sixth semester students of German Department class $\mathrm{C}$ who took Evaluation Im Deutschunterricht course. The digital book was tried out in the form of a complete book with eleven materials presented on Evaluation Im Deutschunterricht course and the chunks of previous materials. After that, the students from class $\mathrm{C}$ were given a questionnaire to record the results of the try out. The result of the questionnaire is visualized in the following figure 3.

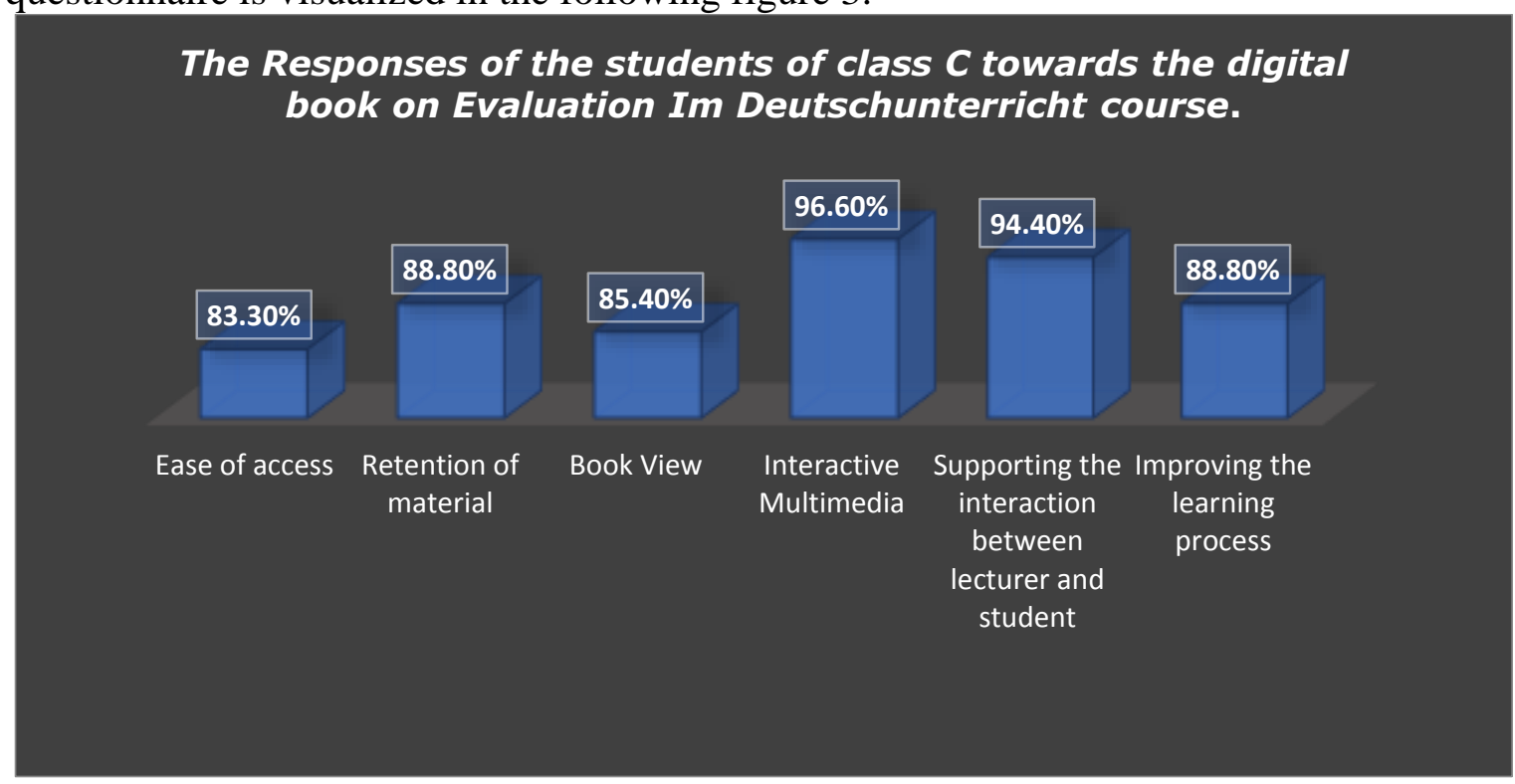

Figure 3. The Responses of the students of class $\mathrm{C}$ towards the digital book on Evaluation Im Deutschunterricht course

\section{The students' Responses towards the Digital Book}

The digital book, which was implemented to the students class $\mathrm{C}$, comprised eleven materials on Evaluation Im Deutschunterricht course. Based on the responses presented in figure 3, it is revealed that $83.3 \%$ of the students did not face any difficulty in accessing the digital book since it could be accessed through various electronic devices such as personal computers, laptops, tablets, and smartphones. Moreover, the students could access the book whenever 
and wherever they are. However, the internet connection of the students influenced their speed in accessing the digital book.

Meanwhile, $88.80 \%$ of the students could understand the materials for they are presented concisely, clearly, and comprehensively. The audios in the digital book are clear and the speed is also reasonable. The speaker used communicative language and a lack of complex terms. The assignments for the students are also understandable.

Based on the visual aspect, $85.40 \%$ of the students agree that the digital book is interesting. It was designed using balanced colours. The layout also draws the students ${ }^{6}$ interest. In addition, the illustrations of the book are suitable with the materials. Those make the book more vibrant.

Based on the interactive multimedia aspect, $96.60 \%$ of the students agree that the multimedia presented in the digital book were interactive for they are completed with many audios, videos, and quizzes. Besides, the multimedia can be accessed without the need to shift to another application. The audios and videos also provide additional information on the materials. The videos are synchronized to youtube so that the students do not need to download the digital book file. The last aspect shows that $94.40 \%$ of students argue that the digital book supports their interaction with their lecturers, wherein the situation of the Covid19 Pandemic, learning activities are done through online platform.

Based on the learning improvisation aspect, $88.80 \%$ of the students stated that this book is able to enhance the learning activity, for everyone can access the digital book in detail in one application. The digital book is also accessible everywhere and at any time. The presence of references in the digital book also enables the students to find the primary learning sources if they want to read the material in detail.

The digital book which was developed for Evaluation im Deutschunterricht course is the latest invention to fulfil the need of learning material in the Covid-19 Pandemic and 4.0 Industry Revolution. This proves that the integration of technology in the form of learning media in education is extended (Kharis, 2020). The presence of digital book enables students of the German Department to access learning materials since the present digital book can be retrieved everywhere and at any time through a range of choice of electronic devices such as personal computers, laptops, tablets, and smartphones. Ruddamayanti (2019) insinuates the same opinion that the digital book has more practicality and feasibility. This is also in line with Makdis (2020) that the purpose of the digital book development was that to facilitate every people to gain access to knowledge and information.

The digital book which was developed in the present research admits copious respectable responses from students. The students argue that the appearance of the digital book is interesting because the researcher included many images, audio, and videos in the visualization. Thus, it does not make the students bored to read. Aji \& Widjanarko (2016) in their research also state that the digital book is more interesting and can trigger the students" learning motivation as well as improve the students' comprehension due to its modification.

The digital book includes numerous interactive features in the form of audio, video, and quiz that can be accessed by the students so that the learning can be more effective and efficient. The implementation of interactive multimedia is aimed at improving the students ${ }^{\text {* }}$ comprehension of concepts and materials of learning (Gunawan, et al., 2004).

The digital book is a solution for the students' learning problems in the pandemic covid19 era where students cannot find learning materials as the library is not easily accessible. Through the present digital book, the students are able to find learning materials (Indariani, et al., 2019), especially in Evaluation im Deutschunterricht course.

The features of interactive media in the form of audio and video is essential to be inserted to materials that need more comprehension such as in the validity test and reliability test on 
Evaluation im Deutschunterricht course. Formulas are involved in, therefore these materials are considered difficult and interactive multimedia are needed so that students can understand them. The mathematical formulas are difficult to be taught since the learning objects are abstract (Fauzi \& Nurfauziah, 2021). Besides, materials with numerical data and calculation are challenging for students with linguistics intelligence (Howard Gardner, 1983). An individual with linguistics intelligence can comprehend a material if it is explained spokenly (Davis, et al., 2011). Considering these two theories, the researcher involved audio and videos of the lecturer's explanation.

The result of the present research can overcome the problems found in Adiarta \& Divayana's (2019) research in diminishing the file size of the digital book, by developing a digital book that can be accessed through an online platform. The digital book has to be accessible through a versatile device like a smartphone, so that the students do not need to use a laptop to access the digital book. It is different from a research result by Seruni, et al. (2019) which was unfeasible for students to access the digital book through a smartphone. The digital book need some adaptation so that it can be compatible in numerous types of smartphone and the students can access the materials using their gadget. Furthermore, the present digital book has been finalized with high order thinking skill (HOTS) evaluation. The HOTS exercises and assignments were not included in Sriwahyuni, et al. (2019).

However, amid all benefits which are included in the present digital book using Flip PDF Professional, there are also some weaknesses. The digital book requires users to have stable internet connection and can only be accessed by using a free website which takes more time. The students who want to download the digital book can only be accessed in HTML format, thus it is unfeasible through a smartphone. In addition, the quizzes included in the present digital book has low resolution, so the students face difficulty in doing the quiz. This is due to a technical issue and the availability of computers and smartphoneS. Therefore, this technical issue lessens the students comfort to access the digital book (Ruddamayanti, 2019).

\section{CONCLUSION}

The digital book which was developed for Evaluation im Deutschunterricht course is the latest invention to fulfil the need of learning material in the Covid-19 Pandemic and 4.0 Industry Revolution. This proves that the integration of technology in the form of learning media in education is extended (Kharis, 2020). The presence of digital book enables students of the German Department to access learning materials since the present digital book can be retrieved everywhere and at any time through a range of choice of electronic devices such as personal computers, laptops, tablets, and smartphones. Ruddamayanti (2019) insinuates the same opinion that the digital book has more practicality and feasibility. This is also in line with Makdis (2020) that the purpose of the digital book development was that to facilitate every people to gain access to knowledge and information.

The digital book which was developed in the present research admits copious respectable responses from students. The students argue that the appearance of the digital book is interesting because the researcher included many images, audio, and videos in the visualization. Thus, it does not make the students bored to read. Aji \& Widjanarko (2016) in their research also state that the digital book is more interesting and can trigger the students" learning motivation as well as improve the students ${ }^{6}$ comprehension due to its modification.

The digital book includes numerous interactive features in the form of audio, video, and quiz that can be accessed by the students so that the learning can be more effective and efficient. The implementation of interactive multimedia is aimed at improving the students ${ }^{\text {* }}$ comprehension of concepts and materials of learning (Gunawan, et al., 2004). 
The digital book is a solution for the students' learning problems in the pandemic covid19 era where students cannot find learning materials as the library is not easily accessible. Through the present digital book, the students are able to find learning materials (Indariani, et al., 2019), especially in Evaluation im Deutschunterricht course.

The features of interactive media in the form of audio and video is essential to be inserted to materials that need more comprehension such as in the validity test and reliability test on Evaluation im Deutschunterricht course. Formulas are involved in, therefore these materials are considered difficult and interactive multimedia are needed so that students can understand them. The mathematical formulas are difficult to be taught since the learning objects are abstract (Fauzi \& Nurfauziah, 2021). Besides, materials with numerical data and calculation are challenging for students with linguistics intelligence (Howard Gardner, 1983). An individual with linguistics intelligence can comprehend a material if it is explained spokenly (Davis, et al., 2011). Considering these two theories, the researcher involved audio and videos of the lecturer's explanation.

The result of the present research can overcome the problems found in Adiarta \& Divayana's (2019) research in diminishing the file size of the digital book, by developing a digital book that can be accessed through an online platform. The digital book has to be accessible through a versatile device like a smartphone, so that the students do not need to use a laptop to access the digital book. It is different from a research result by Seruni, et al. (2019) which was unfeasible for students to access the digital book through a smartphone. The digital book need some adaptation so that it can be compatible in numerous types of smartphone and the students can access the materials using their gadget. Furthermore, the present digital book has been finalized with high order thinking skill (HOTS) evaluation. The HOTS exercises and assignments were not included in Sriwahyuni, et al. (2019).

However, amid all benefits which are included in the present digital book using Flip PDF Professional, there are also some weaknesses. The digital book requires users to have stable internet connection and can only be accessed by using a free website which takes more time. The students who want to download the digital book can only be accessed in HTML format, thus it is unfeasible through a smartphone. In addition, the quizzes included in the present digital book has low resolution, so the students face difficulty in doing the quiz. This is due to a technical issue and the availability of computers and smartphoneS. Therefore, this technical issue lessens the students comfort to access the digital book (Ruddamayanti, 2019).

\section{ACKNOWLEDGMENT}

This article results from research funded by the Faculty of Letters, Universitas Negeri Malang. The funding is based on the Decree of the head of Institute of Research and Community Engagement Universitas Negeri Malang number 4.3.13/UN32/KP/2021.

\section{REFERENCES}

Adiarta, A., \& Divayana, D. G. H. (2019). Pengembangan Soal Test Digital Matakuliah Asesmen dan Evaluasi Menggunakan Aplikasi Wondershare. Jurnal Pendidikan Teknologi dan Kejuruan, 16(2), 287. https://doi.org/10.23887/jptk-undiksha.v16i2.19199 Aji, M., \& Widjanarko, D. (2016). Pengembangan Media Pembelajaran Memahami dan Memelihara Sistem Starter Tipe Konvensional Berbasis Buku Digital Electronic Publication (EPUB). 16(1), 6.

Andina, E. (2011). Buku Digital dan Pengaturannya. 2(1), 18. 
Atmadja, O. S., Karnadi, H., \& Renaningtyas, L. (2015). Perancangan Buku Digital Panduan Perjalanan Wisata Pengendara Sepeda Motor di Pulau Madura. Jurnal DKV Adiwarna, $1(6), 12$.

Berutu, N., Damanik, M. R. S., \& Kabatiah, M. (2021). The Development of Crossfaculty/University Integrated Social Science Learning Model in the Faculty of Social Science, Universitas Negeri Medan. Randwick International of Education and Linguistics Science Journal, 2(2), 215-221. https://doi.org/10.47175/rielsj.v2i2.262

Dewi, F. (2015). Proyek Buku Digital: Upaya Peningkatan Keterampilan Abad 21 Calon Guru Sekolah Dasar Melalui Model Pembelajaran Berbasis Proyek. Metodik Didaktik : Jurnal Pendidikan Ke-SD-an, 9(2), Article 2. https://doi.org/10.17509/md.v9i2.3248

Endryanti, E. R., Wijayati, P. H., \& Roekhan. (2020). Ayo Sinau Basa Jawa: Bahan Digital Penunjang Pembelajaran Kosakata Bahasa Jawa Berbasis Multimedia. 7.

Fauzi, A. \& Nurfauziah, P. (2021). Kesulitan Pembelajaran Daring Matematika Pada Masa Pandemi Covid-19 di SMP Muslimin Cililin. Jurnal Cendekia: Jurnal Pendidikan Matematika. 5(1)

Gardner, Howard. (1983). "Multiple Intelligences (Kecerdasan Majemuk Teori dalam Praktek)

Ghofur, A., \& Kustijono, R. (2015). Pengembangan E-book Berbasis Flash Kvisoft Flipbook pada Materi Kinematika Gerak Lurus sebagai Sarana Belajar Siswa SMA kelas X. 04(02), 5.

Gregory, R. J. (2016). Psychological testing: History, principles, and applications (Updated seventh edition). Pearson.

Gunawan, G., Harjono, A., Sahidu, H., \& Sutrio, S. (2014). Penggunaan Multimedia Interaktif dalam Pembelajaran Fisika dan Implikasinya pada Penguasaan Konsep Mahasiswa. JURNAL PIJAR MIPA, 9(1). https://doi.org/10.29303/jpm.v9i1.38

Harsalinda, R., \& Wijayati, P. H. (2018). Visualisasi sebagai Upaya untuk Memahami Materi Teoritis di dalam Perkuliahan. Journal DaFIna - Journal Deutsch als Fremdsprache in Indonesien, 2(1), 204-217.

Herliantari, H. (2020). Pengembangan Multimedia Flip Module Berbasis 3D Pageflip Professional dengan Pendekatan Flipped Classroom Terintegrasi STEM untuk Meningkatkan Kemampuan Berpikir Kreatif Peserta Ddidik pada Materi Dispersi Cahaya. 110.

Hwan, L. H. (2017). A Study on the Design of Book Design through Digital Edit Design Grid Study - Focused on the Case of Digital Electronic Textbook Based on Pad. Journal Of The Korean Society Design Culture, 23(3), 581-590.

Jeong, K. H. (2013). Development of Design Strategy of Content \& User Interface for Digital textbook to achieve Smart Education: Through Comparative Analysis of Content \& User Interface Design of e-textbook \& Apple Digital textbook. Journal of Digital Design. 13(1), 161-171.

Indariani, A., Ayni, N., Pramuditya, S. A., \& Noto, M. S. (2019). Teknologi Buku Digital Matematika dan Penerapan Potensialnya dalam Distance Learning. Jurnal Nasional Pendidikan Matematika. 3(1):1-12

Jurusan Sastra Jerman Universitas Negeri Malang. (2020). Katalog Jurusan Sastra Jerman 2020. Fakultas Universitas Negeri Malang. http://jerman.sastra.um.ac.id/wpcontent/uploads/2020/12/Katalog-Jurusan-Sastra-Jerman-Agustus-2020.pdf

Kharis, K., Dameria, C. N., \& Ebner, M. (2020). Perception and Acceptance of Padlet as a Microblogging Platform for Writing Skills. International Journal of Interactive Mobile Technologies (iJIM), 14(13), 213. https://doi.org/10.3991/ijim.v14i13.14493

Makdis, N. (2020). Penggunaan E-book pada Era Digital. 8. 
Muhammad, M., Rahadian, D., \& Safitri, E. R. (2017). Penggunaan Digital Book Berbasis Android untuk Meningkatkan Motivasi dan Keterampilan Membaca pada Pelajaran Bahasa Arab. PEDAGOGIA, 15(2), 169. https://doi.org/10.17509/pedagogia.v15i2.8094

Nurjayadi, M., Sadono, R., \& Afrizal. (2021). Development of e-module structure and protein function with flip PDF professional application through online learning. AIP Conference Proceedings, 2331(1), 040029. https://doi.org/10.1063/5.0041891

Purwati, D., \& Nugroho, A. N. P. (2018). Pengembangan Media Evaluasi Pembelajaran Sejarah Berbasis Google Formulir di SMA N 1 Prambanan. ISTORIA: Jurnal Pendidikan Dan Sejarah, 14(1), Article 1. https://doi.org/10.21831/istoria.v14i1.19398

Ruddamayanti, R. (2019). Pemanfaatan Buku Digital dalam Meningkatkan Minat Baca. Prosiding Seminar Nasional Program Pascasarjana Universitas PGRI Palembang, 12(01), Article 01. https://jurnal.univpgri-palembang.ac.id/index.php/Prosidingpps/article/view/ 2750

Saefullah, I. (2017). Membuat Buku Digital Mandiri. Kainoe Books.

Seruni, R., Munawaroh, S., Kurniadewi, F., \& Nurjayadi, M. (2020). Implementation of emodule flip PDF professional to improve students' critical thinking skills through problem based learning. Journal of Physics: Conference Series, 1521, 042085. https://doi.org/10.1088/1742-6596/1521/4/042085

Sofyan, G. A., \& Listiawan, T. (2019). Pengembangan Buku Digital pada Materi Komunikasi dalam Jaringan Mata Pelajaran Simulasi dan Komunikasi Digital Kelas X SMK Perwari Tulungagung. 3, 11.

Sriwahyuni, I., Risdianto, E., \& Johan, H. (2019). Pengembangan Bahan Ajar Elektronik Menggunakan Flip PDF Professional pada Materi Alat-alat Optik di SMA. Jurnal Kumparan Fisika, 2(3), 145-152. https://doi.org/10.33369/jkf.2.3.145-152

Suyasa, P. W. A., \& Divayana, D. G. H. (2018). Pengembangan Buku Digital Mata Kuliah Asesmen dan Evaluasi Berbasis Kvisoft Flipbook Maker. 12

Tarigan, H. G., \& Tarigan, D. (2009). Telaah Buku Teks Bahasa Indonesia. Angkasa.

Thiagarajan, S., Semmel, D., \& Semmel, M. (1974). Instructional Development for Training Teachers of Exceptional Children: A Sourcebook. Council for Exceptional Children, 1920 Association Drive, Reston, Virginia 22091 (Single Copy, \$5. https://eric.ed.gov/?id=ED090725

Wirasasmita, R. H., \& Uska, M. Z. (2017). Pengembangan Media Pembelajaran Berbasis Buku Digital Elektronic Publication (Epub) Menggunakan Software Sigil pada Mata Kuliah Pemrograman Dasar. Edumatic: Jurnal Pendidikan Informatika, 1(1), 11-16 